856

\section{$\longrightarrow$ 芌会}

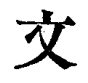

621.664 .01

\section{はすばおよびゃまば転位歯車ポンプの 理論吐出し性能について ${ }^{(1)}$}

市川常 雄(2)

旨車ポンプは歯数が少ないほど时洁し量が多々，效 率も良いので一般に相当少ない荬数か用いられるが。 その場合切り下げをさせるために䎐位菌車を便用する ことが多い：またーつの橧車のすべての橉の摩轮を均

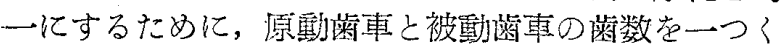
らい変えて扣くこともある。更にある程度大きな菌事 ポンプでは，やま代菌車を使用することが多い。

筆者はこのような一般的な菌車ポンプについて, 理 論吐出し量, 吐出し量の脈動率, 閉込み容積の変化, 逃 げみぞとはすば危との関係等について翆算を行った。

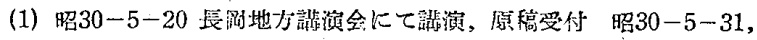

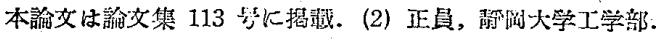

532.526 .2

\section{変分法を用いた虽流境界層の解法(}

(第 3 報)

植松時雄 ${ }^{(2)}$ 八田主爾 ${ }^{(3)}$ 管野 博(4)

第 2 報に打いて，流れの方向に圧力上舁のある場合 の解法を求めたが，同じ場合に対して，境界廨内の速

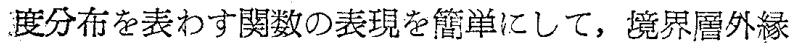
の速度によって変えるべき部分を少くし，計算が篭易 亿できるようにした，ての簡易計算法によっても，結 果は前報のものと大差がない，また徒来と闹様の変分 原理によって，流れの方向に圧才降下のある場合の解 法を求めた。 この場合の解法は，速度分有起わす関 数の表現が異なる外仙，流れの方向に圧力上昇のある 場合と全了同様である。

上上の結果落総合すれば，一様な流れの中に置われ た無限の長さをもつ柱体のま放りの三次元流れの場合 の解法加得られる。乙の場合の㓤として，四杜执よび， だ円桂のまわりの流れについて訪算して, 既知の実跧 結果と比較した。

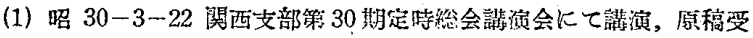

付 昭 30-6-24, 本馀交は諭文集 113 㤐に揭武.

(2)，(3) 正是, 大阪大学工学部. (4) 准員, 大服大学工学部.

621.515.5-226.2 : 533.695.5.001.5 圧縮機用翼型の一翼列実験 ${ }^{(1)}$ 河崎俊夫 ${ }^{(2)}$ 佐藤 義(3)

压力分布を与えて設備した一つの正縮機用翼型の翼 列実験の紹果を述へ，次の結果を得た。

(i ) 王維機用翼列のような減速翼列では, 翼列を 通っての軸流速度の增加が著し〈2次元的性能を示さ なくなる。䡼速度の増加は，側壁の境界圓が主流の 生力上昇のために著しく発迋し，流れが块に集るた め经ずるものである。

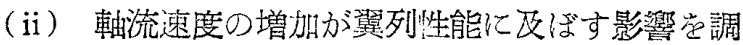
べるために，涌出を寿する 2 次元ポテンシャルの場を 考えて，転向角打よび翼型まわりの圧力分布を算出し て実験值と比較し，相当によく実駼事実を説明でさる ことがわかった。

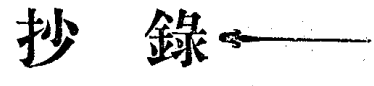

（iii）このモデル普通の翼列実験に封する一つの 修正法を提案するものであるが，更に多くの笑験列に ついて検討するととが望京しい.

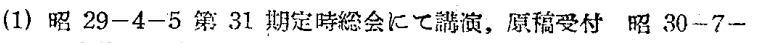

22 , 本諭文は諭女集 113 嗀飞揭载。

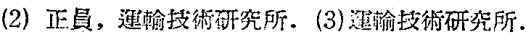

$539.379 .4: 669-17$

\section{結晶粒子の変形と回転から考えた面心立方 \\ 多結晶金属の塑性変形飞ついて}

第片部 変形組織の理論

$$
\text { 大矢根守哉 (2)，小島公平 (3) }
$$

面心立方金属の単結晶に関する実験結果加ら，乙 の種の金属ではすべり面 $\{111\}$ にそってすべり方向 $<110>$ へすべり変形するととが知られている。乙の てとを利用して面心立方金属の多結晶体の変形組織在 理論的に導出したが，その結果はアルミニウムや銅に 関する実験結果とよく一致している。

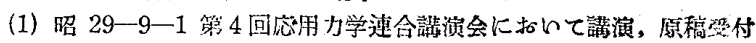

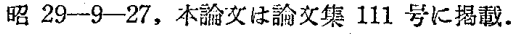

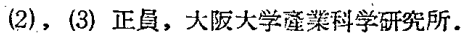

$539.379 .4: 669.295-172$

\section{ちょう密六方金属の变形組織の理論}

(第I 部 チタニウム系金属の場合) (1) 大矢根守载 ${ }^{(2)}$ ，小島公平 ${ }^{(3)}$

ちょう密六方金属のうちのジルコニウム, テタニウ ム，ベリリウムに関する変形組織の理論を面心立方金 属の場合と同様なち法によって考えた。てれらの金属 の単結晶についでの実験によれば，すべり変形は面 $\{0001\}$ 打よび面 $\{1010\}$ にそって方向<1210> へ生 じまた双晶変形は面 $\{1012\} ，\{1121\} ，\{1122\}$ 亿生

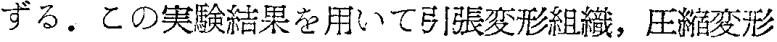
組織，正延組織を求めてみたが，その結果はX線によ る実験結穌と同一であった。

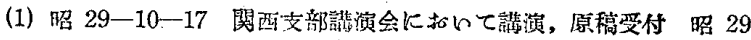

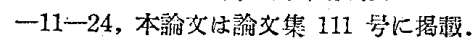

(2), (3) 正虽, 大阪大学窟業科学研究所.

$539.379 .4: 669 .-17$

\section{体心立方金属の変形組織の理論 (1)}

大矢根守哉 ${ }^{(2)}$, 小島公平 (3)

体心立方金属の䓓結晶㳊関する実験結果汃ら，ての 種の金属ではすべりは面 $\{110\},\{112\} ，\{123\}$ 亿坐ず るととが知られている。このてとを利用して体心立方

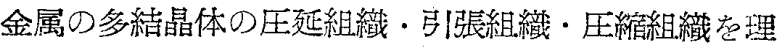
論的に導出したが，その続果は各变形組織とも $\alpha$ - Fe, シリコンフェライトに関する実験結果とよく一致して いる。

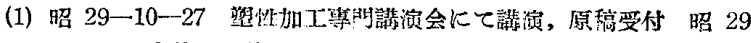

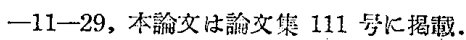

(2), (3) 正是, 大阪大学紊策科学研究所.

$621-253-756: 539.31$

厚い中空回転円板の応力と変形(1)

今 井恶一蚛 ${ }^{(2)}$

厚さ一様な回転円板の応力分布扣よび変形を知るこ 